\title{
LEAD AND WINE EBERHARD GOCKEL AND THE COLICA PICTONUM
}

\author{
by \\ JOSEF EISINGER*
}

\begin{abstract}
THE colica Pictonum or colic of Poitou, under these and many other names, was a frequent, widespread, and deadly disease from Roman times until the eighteenth century. Its unique pathognomonic, notably a severe colic succeeded by paralysis and other central nervous system dysfunction, makes it possible to identify the disease with certainty as chronic lead disease, usually caused by the ingestion of lead-adulterated wines. The custom of sweetening and preserving sour wines with lead-containing additives is traced to the Romans. They had made the empirical discovery that sapa, a syrup prepared by concentrating must in a lead vessel, kept wine from spoiling and that it had, moreover, an agreeable flavour.

Reports of outbreaks of the colica Pictonum appear in the medical literature from Roman times, but the correct aetiology of the disease was not discovered until the seventeenth century following a series of outbreaks in Southern Germany which were related to unfavourable climatic and political conditions. The connexion between the disease and prevailing methods for "correcting" wines was drawn in 1696 by Eberhard Gockel, then the city physician of Ulm. This achievement can be traced to his familiarity with Samuel Stockhausen's work on plumbism among miners and potters, as well as to the favourable epidemiological situation presented by Gockel's monastic patients.

From the literary evidence assembled here and from experimental determinations of the lead content of sapa and similar concentrates, it is possible to estimate the lead levels and toxicity of wines from various eras. The levels range up to $80 \mathrm{mg} / \mathrm{l}$ and make it apparent that many wines were sufficiently toxic to account for the incidence and severity of the colica Pictonum. Explanations for the disastrous persistence of the colic of Poitou are discussed, as are the similarities between Gockel's approach and the methods of modern environmental medicine.
\end{abstract}

\section{INTRODUCTION}

The last century has seen a great increase in the quantity and variety of pollutants in our environment and with it has grown the apprehension that our air, food, and water supply may contain unsuspected disease-causing agents. If the incidence of disease caused by them is either very low or else very widespread, such agents are notably difficult to identify, particularly if their effects are cumulative or delayed by long lag-

*Josef Eisinger, Ph.D., Bell Laboratories, Murray Hill, N.J. 07974, U.S.A. 


\section{J. Eisinger}

periods following exposure. If, on the other hand, a particular population group, because of its lifestyle or occupation, is exposed to high levels of a particular intoxicant, an environmental epidemic may break out among them. Such epidemics constitute "natural experiments" and sometimes permit the alert physician to identify previously unsuspected intoxicants.

It was by the very same approach that Eberhard Gockel, a relatively unknown German physician, discovered in 1696 the origin of what may well be the most widespread and longest lasting of such environmental epidemics and pandemics. The disease in question was the colica Pictonum and, while it is rare today, it raged in many parts of Europe and elsewhere for many centuries. An intensely painful and debilitating disease, which frequently ended in death, the colica Pictonum caused great suffering until it was largely eliminated in the eighteenth century. The mode by which it was eventually recognized as chronic plumbism, caused usually, but not always, by the consumption of lead-adulterated wines, contains remarkable parallels to modern approaches of environmental medicine. Beyond this, the history of colica Pictonum illustrates the complex interplay which exists between human disease and social, economic, and natural forces.

\section{THE COLICA PICTONUM}

\section{Symptoms and Outbreaks}

The disease whose history is traced here was known by many names, but the one most frequently used in the medical literature from the seventeenth century onwards, is the colic of Poitou or the colica Pictonum, the Pictones being the inhabitants of Poitou. It was first used by Francis Citois, who provided a classical description of the disease in 1639 (see Appendix 1). ${ }^{1}$ It is an appropriate name, for the colica Pictonum was endemic in the region for many generations and in the seventeenth century the majority of the population suffered from it. ${ }^{2}$

The early symptoms are variable and often include headache, fatigue and fever, restlessness and insomnia, loss of appetite, lethargy and diarrhoea. Its later stages are marked by severe and even complete constipation, often associated with an inward contraction of the umbilical region, and colic pains. When it was a fairly common disease, some doctors considered the anguish it caused its victims the worst of any affliction., Jaundice, due to liver dysfunction, occurs frequently. Eventually various disturbances of the central nervous system predominate. These often include loss of control of the extremities without loss of feeling ("hand and foot drop"), loss of speech, deafness, blindness, visions and insanity, paralysis, and eventually even death. ${ }^{5}$

These symptoms can be understood in terms of the fundamental interactions between lead and the living system. Lead ions $\left(\mathrm{Pb}^{2+}\right)$ have a propensity for binding to the sulphydryl (S-H) residues of proteins. Most enzymes (proteins) have one or more

\footnotetext{
' Francis Citois [Citesius], De novo et populari apud Pictones dolore colico bilioso diatriba, Paris, 1639.

${ }^{2}$ I. Boucher Beauval, Traité de la populaire colique bilieuse de Poitou, La Rochelle, 1673.

3 Johanne Grashuis, De colica Pictonum tentamen, Amsterdam, 1752.

4 Eberhard Gockel, Eine curiose Beschreibung dess An. 1694. 95 . und 96 durch das Silberglett versüssten sauren Weins und der davon entstandenen neuen und vormals unerhörten Wein-Kranckheit ..., Ulm, 1697.

${ }^{s} \mathrm{~L}$. Tanquerel des Planches, Traité des maladies de plomb ou saturnine, Paris, 1839.
} 


\section{Lead and wine}

of such residues and are therefore liable to be inhibited by lead ions, frequently at micromolar levels (approx. $0.2 \mathrm{ppm}$ ). It is because most of the body's absorbed lead is stored in the skeleton, where its residence time is many years, that lead is a cumulative poison. As the lead level in soft tissue, which is in equilibrium with that in the skeleton, rises, different enzyme systems and organs are affected at times which depend on the rate at which lead is ingested and excreted. This accounts for the wide spectrum of symptoms. Soon the destructive effects of lead on the nervous system predominate and lead-colic is due to the paralysis of the peristaltic movement of the gut. $6,7,8$

One of the earliest reports about the disease is by the Byzantine physician Paul of Aegina (fl. A.D. 600), who listed among its symptoms the painful retention of faeces and urine, vomiting, fever, and sleeplessness, and clearly believed that it was a frequent and widespread problem in the ancient world.'

I am of the opinion that the colic affection which now prevails is occasioned by such humours; the disease having taken its rise in the country of Italy, but raging also in many other regions of the Roman empire, like a pestilential contagion, which in many cases terminates in epilepsy, but in others in paralysis of the extremities, while the sensibility of them is preserved, and sometimes both these affections occur together, and of those that fell into epilepsy the greater number died; but of the paralytics the most recovered ....

The syndrome of symptoms of the colica Pictonum and those of the Devonshire colic, the bilious colic, the paralytic, spasmodic, or epileptic colic, the saturnine colic, the German "Grimmen", and the English and American "dry belly-ache", "gripes", or "griping of the guts" are all the same, and written accounts differ only in emphasis. There can be no doubt that they all are the same disease, whose pathognomic may be found in all important medical works until the eighteenth century. Avicenna (980-1037) observed many epidemics, Paracelsus (1493-1541) encountered it frequently in Germany, France, and Switzerland, ${ }^{10}$ and Thomas Sydenham (1624-1698) offered this succinct description of the disease: ${ }^{11}$

This is the sort of colic which is wont to degenerate into palsy, depriving the patient of the use of both hands and feet (a fact noted by Riverius in his chapter on Palsy) and which is extremely common in the West Indies, where it destroys many persons.

Balsam of Peru in large and frequent doses is the cure for the pain .... This, however, will not cure the palsy.

\section{Prevalence of the Colic of Poitou}

Before the era of printed books and the proliferation of a periodic medical literature

- B. L. Vallee and D. D. Ulmer, 'Biochemical effects of mercury, cadmium and lead', Ann. Rev. Biochem., 1972, 41: 91-128.

' J. L. Granick, S. Sassa and A. Kappas, 'Some biochemical and clinical aspects of lead intoxication', Adv. Clin. Chem., 1978, 20: 287-339.

'Josef Eisinger, 'Biochemistry and measurement of environmental lead intoxication', Quart. Rev. Biophys., 1978, 11: 439-462.

- Paulus Aegineta, Lib. III, Sec. 43, trans. and ed. by Francis Adams, 3 vols., London, Sydenham Society, $1844-47$.

${ }^{10}$ George Baker, "An attempt towards an historical account of that species of spasmodic colic, distinguished by the name of the colic of Poitou', Med. Trans. Coll. Phys. Lond., 1768, 1: 319-363.

${ }^{11}$ Thomas Sydenham, 'Processus integri', ch. XXV, 1693, in The works of Thomas Sydenham, trans. by R. G. Latham, 2 vols., London, Sydenham Society, 1848-50. 


\section{J. Eisinger}

which began in the seventeenth century, ${ }^{12}$ written reports of outbreaks of the colica Pictonum were naturally sporadic.

That the disease was common enough can be seen from the fact that a medical bibliography published in the eighteenth century contains no fewer than a thousand entries under colica, many of which deal with colic-paralysis..$^{13}$ There are, in addition, some 300 entries under colica saturnina ${ }^{14,15}$ and colica Pictonum, and these listings are certainly incomplete.

Epidemics often involved members of the same family or, not infrequently, monks in a particular monastery. ${ }^{1,4}$ Epidemic outbreaks were, of course, recognized as such only if several victims developed the symptoms at about the same time. Because lead is a cumulative poison, this happened generally only when the lead content of the wine was so high that the symptoms of the colica Pictonum appeared within, say, a few weeks after the leaded wine began to be consumed. Otherwise, the symptoms would appear at variable times, depending on the rate of consumption and on other factors. Specific symptoms, such as paralysis, might not appear for several years.

From the sixteenth to the eighteenth century, epidemics frequently occurred in many parts of France, Italy, Spain, Bohemia, Moravia, Sweden, Holland, England, Silesia, Switzerland, Germany, and Austria, ${ }^{10,16,17.18}$ and were often reported to be common in the autumn and following cold summers. In fact, contemporary physicians repeatedly blamed outbreaks of the colica Pictonum on sour and harsh vintages which were the result of short and cold grape growing seasons. ${ }^{17.19 .20}$ These correlations were real enough, but generally resulted from the use of lead-containing additives to "sweeten" sour vintages.

In the Americas, the disease was often called the West-Indian dry gripes and in the eighteenth century was considered endemic. ${ }^{21}$ It was generally caused by rum from stills equipped with lead condensers. Because metallic lead had been endowed with great "frigidity" by doctors and alchemists since ancient times, it was the material of choice for condensers ("worms") in early stills. It is, therefore, not surprising that

\footnotetext{
${ }^{12}$ H. E. Sigerist, 'The medical and scientific periodicals of the seventeenth and eighteenth centuries', Bull. Inst. Hist. Med. (Johns Hopk. Univ.), 1934, 2: 285-343.

${ }^{13} \mathrm{G}$. G. Ploucquet, Initia bibliothecae medico-practicae et chirurgiae, Tübingen, 1794. (Supplements published in 1799 and 1802.)

14 The planet Saturn has long been associated with the metal lead and astrologers, doctors, and alchemists employed the same symbol, $h$, for both. Similar pairings are: Sun and gold, $\odot ;$ moon and silver, $D ;$ Venus and copper, $\$$; Mars and iron, $\delta$; Mercury and mercury, $\zeta$.

is M. P. Crosland, Historical studies in the language of chemistry, London, Heinemann, 1962 (reprinted, New York and London, Dover Publications, 1978).

16 [Pierre Massuet], 'Tractatus de colica Pictonum', Bibliothèque raisonnée des savans de l'Europe, Amsterdam, 1732: vol. 8, part 1, art. II, 30-77; vol. 9, part 1, art. IV, 144-173; vol. 9, part 2, art. II, 279-312.

${ }^{17} \mathrm{~T}$. Tronchin, $A$ treatise on the colica Pictonum; or the dry belly-ache, trans. and ed. by R. Schomberg, London, 1764 (original ed., Geneva, 1757).

$18 \mathrm{~J}$. Huxham, A small treatise on the Devonshire colic which was very epidemic in the year 1724, London, 1788 (original ed., London, 1759).

19 Daniel Sennert, Opera omnia in tres tomos distincta, Paris, 1641.

20 Ralph H. Major, 'Some landmarks in the history of lead poisoning', Ann. med. Hist., 1931, N.S. 3: 218-227.

${ }^{21}$ Thomas Cadwalader, An essay on the West India dry-gripes with the method of preventing and curing that cruel distemper, Philadelphia, B. Franklin, 1745.
} 


\section{Lead and wine}

lead was a common contaminant of rum. ${ }^{22,23,24}$

In eighteenth-century England, the colica Pictonum, also known as the Devonshire colic, after the most important apple-growing county, was frequently caused by cider contaminated by lead dissolved from leaden fittings of presses and vats. ${ }^{25} \mathrm{~A}$ contemporary epidemic in Amsterdam was traced to drinking-water collected from lead roofs. It had broken out in the autumn, after the leaves which had collected on the roofs had decayed and acidified the rain-water. ${ }^{17}$

\section{Therapies}

Most medical accounts of the colica Pictonum devote as much space to its cures, as to the description of its symptoms and supposed causes. But, since these therapies have little bearing on the present investigation, we will discuss them only briefly.

An effective therapy of chronic plumbism would require the reduction of the patient's body burden of lead. Chelating drugs, which strongly bind lead ions in blood and thereby facilitate their excretion, can achieve this in time, but chelation therapy has only recently been available. ${ }^{26}$

The many different treatments recommended in the early medical literature were largely ineffective in speeding up the normal gradual elimination of the body's lead. Since the disease has a tendency to wax and wane and its symptoms change with time, it is not surprising that many doctors nevertheless claimed to have discovered useful cures. Some of these were clearly disastrous, such as lead-containing medicines ${ }^{17}$ or the eighteen ounces of mercury given an unfortunate American victim of the colica Pictonum a day before he died. ${ }^{21}$

Other therapies of doubtful value include venesection and many varieties of purgatives, emetics, and enemas. ${ }^{4,18}$ According to an eighteenth-century folk remedy, a dog lying across the patient's stomach would, because of the sympathy dog feels for man, take the colic pains on to himself. ${ }^{27}$

Astute doctors conceded that the available therapies were useless in most cases and concentrated their efforts on relieving the anxiety of the patient and providing symptomatic relief. Some cautioned against excessive bleeding, ${ }^{28}$ and they frequently provided opiates (which Huxham considered "that most beneficent Gift of Heaven to the Miserable, Opium"), to lessen the excruciating pain. ${ }^{18}$ Other physicians recommended external medication to accomplish the same end, though one wonders about the application of toast smeared with unsalted butter to the patient's stomach and

\footnotetext{
22 The first legislation against this dangerous practice was enacted in Boston, Mass., in 1723, and appears to have been instigated by Benjamin Franklin. (See note 24 below.)

${ }^{23}$ George Baker, 'An examination of several means, by which the poison of lead may be supposed frequently to gain admittance into the human body, unobserved and unsuspected', Med. Trans. Coll. Phys. Lond., 1768, 1: 257-318.

${ }^{24}$ Benjamin Franklin, a letter quoted in Reginald Fitz, "A note on the history of lead poisoning in Boston', New Engl. J. Med., 1934, 25: 802-806.

${ }^{25}$ H. A. Waldron, 'The Devonshire colic', J. Hist. Med., 1970, 25: 383-414.

${ }^{26}$ A. Catsch and A. E. Harmuth-Hoene, 'Pharmacology and therapeutic applications of agents used in heavy metal poisoning', in W. G. Levine (editor), The chelation of heavy metals, Oxford, Pergamon Press, 1979.

${ }^{27}$ Johann H. Zedler, Universal Lexicon, vol. 6, 1733.

Jean Baptiste Du Bois, Non ergo colicis figulis venae sectio, Paris, 1751.
} 


\section{J. Eisinger}

back, ${ }^{29}$ or the application of cinnabar (mercuric sulphide). ${ }^{30}$ Several doctors held horse-riding to be beneficial for strengthening the viscera weakened by the disease. ${ }^{18.21}$

\section{THE LEGACY OF SAPA}

\section{The Origins of Leaded Wines}

After presenting the evidence for the wide distribution and severity of the colica Pictonum we turn our attention to the origins of the wine treatments which often gave rise to the disease. "Leaded wines" can be traced with certainty to ancient Rome, and their prevalence grew with the expansion of Rome's borders. While the archaeological evidence is sketchy, ${ }^{31}$ the literary evidence for this hypothesis will be seen to be persuasive.

Wine had not always been the predominant beverage of the Roman world. Pliny relates that under Romulus and King Numa, that is in the early days of the Republic, wine-drinking was discouraged and was permitted only to men over thirty-five. Winedrinking was entirely forbidden to women, and when Equatius Maetennus clubbed his wife to death for violating this rule, the homicide was considered justifiable. ${ }^{32}$ Heavy drinking became acceptable, first for men and later for women, only during the days of the Empire. ${ }^{33}$ Hundreds of varieties of wine are described by Pliny in his Natural history (c. A.D. 75) and large quantities of wine were shipped to Rome and other Italian cities from all Mediterranean countries. ${ }^{32}$

As wine consumption grew, so did wine adulteration. Martial, in one of his poems, accuses Munna, a wine merchant in Massilia (Marseilles), of shipping overseas his deadly poisons at a high price, and he suggests that his fear of having to drink his own wines was the reason for Munna's reluctance to travel to Rome. ${ }^{34}$ There is little doubt that the art of doctoring wines was widely practised in the Roman Empire, and Pliny complains of it repeatedly. ${ }^{32}$

While the mixing and "correcting" of wines was widely deplored, the rarity of glass bottles, corks and, most of all, sterile conditions for fermenting and storing wines, made it necessary to use some sort of preservative to keep wines from spoiling. The Greeks preferred resin-based additives for the purpose, and the modern Greek retsina is a descendant of such wines. The Romans, on the other hand, commonly used as a preservative a syrup variously called sapa, defrutum, or caroenum, the name being sometimes used to denote the degree to which the syrup had been reduced. These syrups were prepared by simmering must (unfermented grape juice) in a leaden vessel over a slow fire until it was reduced in volume to about one-third. Recipes for preparing them are given by several Roman authors including Pliny, who understood the preservative properties of sapa very well.

\footnotetext{
29 Eberhard Gockel, 'Colica epidemia maligna', Consiliorum et observationum medicinalium ..., Dec. III, Obs. 7, 1683.

${ }^{30}$ George Baker, An essay concerning the cause of the endemial colic of Devonshire, London, 1767.

${ }^{31}$ Lloyd G. Stevenson, 'A history of lead poisoning', doctoral dissertation, Johns Hopkins University, 1949.

32 Pliny the Elder, Naturalis historia, Lib. XIV, ch. 14.

${ }^{33}$ Friedrich von Bassermann-Jordan, Geschichte des Weinbaus, Frankfurt, 1923.

34 Martial, Epigram. X, 36.
} 


\section{Lead and wine}

The jars [of wine] must never be filled quite full and the space above the surface of the wine must be smeared with passum [raisin wine] or defrutum mixed with saffron or iris pounded up with sapa. The lids of the jars should be treated in the same way, with the addition of mastic or Bruttian pitch .... Also, the defrutum and sapa should be boiled when there is no moon . . . and moreover leaden and not bronze vessels should be used. ${ }^{3 s}$

The most detailed instructions for the preparation of sapa and how to preserve wines with it, have come down to us from Columella. He was a wealthy Spanish landowner, who owned estates in various parts of central Italy. In about A.D. 80, he published a comprehensive treatise on the management of a commercial agricultural estate, which includes these remarks: ${ }^{36}$

One should take care that the stored must does not spoil for a year, or at least until it is sold. I will now show how this is achieved and what means may be useful in this. Some allow a quarter of the must to boif away after pouring it into leaden pots, some a third. If one lets half of it boil away, it becomes undeniably a better sapa....

Even carefully prepared defrutum often turns sour just like wine. This being so, one should flavour the wine only with defrutum which is a year old and whose quality is proven. Only by good means can a good end be achieved ....

\section{The Uses of Sapa}

It appears that at some time during the days of the Republic, the Romans discovered that sapa, when added to wine or fruits, would keep them from spoiling. The syrup had, moreover, an appealing colour, fragrance, and sweet taste, which made sapa wine, according to several contemporary authors, particularly popular among women. ${ }^{33}$ By the same token, sapa became a favourite ingredient in Roman cooking, ${ }^{37.38}$ particularly for the preparation of meats and sauces. As such, though one hopes not always prepared in a leaden vessel, it continued to be employed in Italian and French cooking until the nineteenth century and was sometimes known as "sabe".38,39

Another example of the remarkable appeal and persistence of sapa wine is provided by Marsala, a still-popular Sicilian dessert wine, whose dark amber colour and flavour of burnt sugar derives from "the addition of grapejuice that has been cooked and reduced to about one-third of its original volume"..40

In addition to having a pleasing taste, sapa is indeed an effective preservative. It derives this quality from its high lead content (see below and Table I) and the inhibitory effect which lead ions exert on enzyme systems and, therefore, on living organisms. ${ }^{41,8}$

\footnotetext{
${ }^{3 s}$ Pliny, op. cit., note 32 above, Lib. XIV, ch. 27.

${ }^{36}$ Columella, De re rustica, Lib. XII, ch. 19-21.

${ }^{37}$ Caelius Apicius, Cookery and dining in Imperial Rome, trans. by J. D. Vehling, Chicago, 1936 (reprinted, New York, Dover Publications, 1977).

$38 \mathrm{~J}$. Beckmann, History of inventions, discoveries and origins, trans. by Wm. Johnstone, London, 1846, vol. 1, pp. 245-258.

${ }^{39}$ Edmond Huguet, Dictionnaire de la langue francais du XVI siècle, Paris, 1965. (See entry under 'Sabe'.)

${ }^{4}$ Encyclopaedia Britannica, 1974, vol. 19, p. 883.

${ }^{4}$ The lethal effect of lead ions on bacteria was known and exploited for centuries. Before the advent of modern antibiotics, lead ointments and lead solutions, also known as "Water of Goulard", provided effec-
} 


\section{J. Eisinger}

\section{The Toxicity of Sapa}

The toxicity of sapa and of the wines treated with it can be estimated by analysing the syrup prepared according to the directions of Columella, Pliny, and other Roman authors. ${ }^{32,36,42}$

By simmering grape-juice in a lead-lined pot until it was reduced to one-third of its original volume, we obtained a dark brown and tasty syrup with the consistency of thin honey and a fragrance resembling that of molasses. While the level of lead in any particular preparation of sapa depends somewhat on the rate of heating, the acidity of the must, and the size and shape of the vessel in which it is prepared, we determined, by using atomic absorption, that Roman sapa contained approximately 1 gram of lead per litre. ${ }^{43} \mathrm{~A}$ similar value was obtained in an earlier experiment. ${ }^{44}$ The potency of sapa is also suggested by its medicinal uses. Pliny recommends a potion consisting of sapa and onions to bring on abortions. ${ }^{45}$ If the onions are discounted as active ingredients, the efficacy of this prescription would follow from the well-known abortifacient properties of ingested lead.

In order to estimate the toxicity of wines treated with sapa, it is, of course, necessary to know the proportion in which it was added to wine. Fortunately, Columella supplies specific instructions on this point. Although consideration was given to the vintage and to how long the wine was to be kept, his general rule was that a sextarius of thickened defrutum should be added to an amphora of wine (i.e., $1: 48$ ). Columella points out that the correct ratio also depends on the consistency of the

tive protection against bacterial infection of wounds and burns and they were widely used into the twentieth century.

The Scottish physician Thomas Percival, for example, published an early epidemiological study of a gunpowder explosion in Chester in 1772, in which many were killed and injured. Thirty-three victims suffering from the most serious burns and contusions were admitted into the infirmary, and after being treated by repeated washings with "Goulard's saturnine waters", were free from infections the next day. Twenty others, on the other hand, who had suffered incomparably less severe injuries, had to be admitted to the infirmary during the following days because they suffered severe burning pain in their highly inflamed wounds (Thomas Percival, Observations and experiments on the poison of lead, London, 1774).

The external use of lead solutions undoubtedly caused some lead poisoning but its benefits often outweighed its dangers. Lead-containing potions, on the other hand, although decried by many famous physicians from Roman times on, were popular into the early 19th century and caused much suffering and many deaths (J. B. Gray, 'Colic pictonum from the medicinal employment of acetate of lead', Lancet, 1841-42, i: 123; Jacqueline Corn, 'Historical perspective to a current controversy on the clinical spectrum of plumbism', Health and Society, winter 1975, 93-114). Doctors and quacks alike frequently prescribed high doses of Tinctura or Saccharum Saturni against various disorders, including fevers, gonorrhoea and spitting blood. Paracelsus was a firm believer in saturnine medicines and probably contributed to some of the outbreaks of the colica Pictonum which he observed in the course of his peripatetic practice (Baker, op. cit., note 10 above). An eighteenth-century physician relates a case of a young man who had received lead medication from a quack and suffered a terrible colic as a result. A doctor was called in and when the patient developed a fever, he prescribed saccharum saturni, which, we are told, "carried off and removed the fever; but it brought on a convulsive colic" (Tronchin, op. cit., note 17 above).

Serious, frequently fatal, lead disease was also caused by cosmetics. In Georgian England, for instance, the custom of painting one's face with white lead, sometimes to hide pock marks, but usually because fashion demanded it, was widespread and cost many men, as well as women, their health or life (Elizabeth Burton, The Georgians at home, London, Longmans, Green, 1967, ch. 8).

42 M. Porcius Cato, De agricultura, ch. 105, 107, 122.

43 Josef Eisinger and Jorge Flores, unpublished experiments, 1979.

4 K. B. Hofmann, 'Das Blei bei den Völkern des Altertums', in F. Dentike (editor), Beiträge aus der Geschichte der Chemie, Leipzig and Vienna, 1885.

us Pliny, op. cit., note 32 above, Lib. XIII, ch. 30. 


\section{Lead and wine}

\section{TABLE I}

\section{Estimated Lead Content of Extracts and Wines}

\section{Comparison with Toxicity Limits}

$\begin{array}{lccc} & \begin{array}{c}\text { Dilution } \\ \text { Factor } \\ (\mathrm{v} / \mathrm{v})\end{array} & \begin{array}{c}\text { Lead } \\ \text { Content } \\ (\mathrm{mg} / \mathrm{l})(\mathrm{a})\end{array} & \text { Notes } \\ \begin{array}{l}\text { Extracts } \\ \text { sapa, first century }\end{array} & - & 1000 & \text { (b) } \\ \begin{array}{l}\text { Württemberg, seventeenth century } \\ \text { Wines }\end{array} & - & 16000 & \text { (c) } \\ \text { Roman, first century } & 48(24-288) & 20 & \text { (b) } \\ \text { Württemberg, seventeenth century } & 240(160-320) & 70 & \text { (d) } \\ \text { Württemberg, seventeenth century } & 640 & 20 & \text { (e) } \\ \text { Württemberg, seventeenth century } & 2000 & (8) & \text { (f) } \\ \text { Colic patients, twentieth century } & - & 7.5 & \text { (g) } \\ & - & 12 & \text { (h) } \\ \text { Devonshire ciders, 1767 } & - & 5,14 & \text { (i) } \\ \text { Fortified wines, 1770-1820 } & - & 0.3-2 & \text { (j) } \\ \text { Sensitivity of Gockel's assay } & & 10 & \text { (c) } \\ \text { Chronic toxicity limit (mg/d) } & & 0.5 & \text { (k) }\end{array}$

Notes

(a) The figures in this column also represent a person's lead intake in $\mathrm{mg} / \mathrm{day}$, if a litre of wine is consumed per day. This rate of consumption is a conservative estimate for the first and seventeenth centuries. ${ }^{33}$

(b) Prepared according to Columella's instructions. ${ }^{36}$ The lead content was determined experimentally. ${ }^{43}$

(c) According to Gockel's instructions. ${ }^{4}$

(d) By the glass. ${ }^{4}$

(e) By the cask.4

(f) Considered a "moderate" recipe by Reisel." The recipe for preparing the extract is not given. The same lead content as that in the Württemberg extract was assumed.

(g), (h) The lead concentrations of two home-made wines kept in lead-glazed jars are given. Both patients were admitted to hospitals, suffering from lead colic, after having consumed c. $0.2 \mathrm{l} / \mathrm{d}$ of wine for about 2 and 1 years, respectively; $(\mathrm{g})$ : footnote $74 \mathrm{a}$; $(\mathrm{h})$ : footnote $74 \mathrm{~b}$. The total amount of ingested lead was therefore approximately $1 \mathrm{~g}$ for both patients.

If Gockel's patients had drunk $11 / \mathrm{d}$, they would have ingested this amount lead in about 2 weeks.

(i) According to experiments V and VI, footnote 30.

(j) See footnote 87.

(k) See footnote 47

defrutum and the availability of wood for reducing it, and that his neighbours add more than he does. He also warns that too high a proportion of sapa should be avoided, lest its flavour be noticeable and scare off the buyer. We may conclude from this remark that this method of correcting wines was not embraced by the winedrinking public.

While this treatment could not be counted on to preserve wine indefinitely, Columella considered that it should generally permit the wine to last until the next harvest. Usually, various spices were added to the wine along with the sapa and Columella calls for the addition of a pound of crushed spices to a vessel containing ninety amphoras of previously boiled-down defrutum. If the original charge of the kettle was three times as great, or $\mathbf{2 7 0}$ amphoras, the lead kettle must have had a capacity in 


\section{J. Eisinger}

excess of 8,000 litres, $^{46}$ and if it was hemispherical in shape, its diameter was about three metres! It is clear that Columella was dealing with wine production on a commercial scale. ${ }^{36}$

From the lead content of sapa and Columella's directions we can estimate the lead content of his wines. The recommended proportion of wine to sapa (or defrutum) ranges from 24 to 288 , with 48 being the most frequently mentioned dilution factor. The lead content of Columella's wines must therefore have been approximately $20 \mathrm{mg} / \mathrm{l}$, so that a person consuming one litre of wine per day would ingest about $20 \mathrm{mg}$ of lead per day. This intake can be compared with $0.5 \mathrm{mg}$ per day which is considered to produce chronic lead poisoning (see Table 1). ${ }^{47}$

The prevalence of chronic lead poisoning which resulted from the free use of sapa and from the huge wine consumption of the Romans, was known to many scholars at the end of the nineteenth century, when interest in the classical world was high. Endemic lead disease may indeed have been a reason why sterility was commonplace, particularly among the Roman aristocracy. ${ }^{44,48,49,50}$ While some have ascribed the demise of many patrician families and the failure of most emperors to provide natural heirs to excessive lead intake, the historical validity of the suggestion that it contributed to the political decline of the Roman Empire, ${ }^{31}$ remains questionable. $^{30}$

\section{The Derivatives of Sapa}

It seems likely, that recipes for as efficacious a preservative as sapa were passed on by generations of vintners and wine merchants, particularly since the additive had the extra virtue of sweetening and hiding the harshness of sour wine..$^{32}$ Even if this had not been the case, the art of sweetening and preserving wines with the aid of lead would not have been lost: Columella's book, De Agricultura, saw at least six editions in both Latin and German between 1491 and 1769. ${ }^{33}$

Certainly, the following recipe from the year 1697 bears a striking resemblance to the Roman recipe, although the intervening sixteen centuries had enhanced its chemical sophistication: ${ }^{54,4}$

\footnotetext{
${ }^{46}$ A standard amphora, the fundamental liquid measure, was kept in the Capitol in Rome. Its volume was about 26 litres.

1 amphora $=2$ urnae $=8$ congii $=48$ sextarii; 1 sextarius (about 0.5 litres) $=3$ trienses $=4$ quadrantes.

${ }^{47}$ R. H. Dreisbach, Handbook of poisoning. Diagnosis and treatment, 9th ed., Los Altos, Calif., Lange Medical Publications, 1977.

* Jerome Carcopino, Daily life in Ancient Rome, trans. by E. O. Lorimer, New Haven, Conn., Yale University Press, 1940.

49 Rudolf Kobert, 'Chronische Bleivergiftung im klassischen Altertume', in Dentike (editor), op. cit., note 44 above.

${ }^{50}$ H. A. Waldron, 'Lead poisoning in the ancient world', Med. Hist., 1973, 17: 391-399.

s1 S. C. Gilfillan, 'Lead poisoning and the Fall of Rome', J. occup. Med., 1965, 7: 53-60.

32 The divalent lead ion, $\mathrm{Pb}^{2+}$, has a sweet taste, which is the reason why some children crave leadcontaining paint chips. This so-called lead pica is a major cause of lead disease among young children, today, particularly among those living in dilapidated housing. (H. A. Waldron and D. Stöfen, Sub-clinical lead poisoning, London and New York, Academic Press, 1974.)

s3 Karl Ahrens, Columella Ueber Landwirtschaft, Berlin (DDR), Akademie-Verlag, 1972, p. 39.

s4 Eberhard Gockel, 'De vini acidi per acetum lithargyri cum maximo bibentium damno dulcificatione', Ephemerides (Misc. Curiosa), Dec. III, Ann. 4, Obs. 30, 77-85, 1697.
} 


\section{Lead and wine}

Put into a vessel 6 Unzen or 12 Loth of powdered litharge (others use twice as much and add bismuth or marcasite) and add one measure [Ulmer Mass] of 3 Libra and 4 unciae of good vinegar; simmer until the volume is reduced by quarter. Pour into a glazed vessel, add one measure of the best wine or Malvoisie and simmer down some more. Filter and store in a well sealed glass for use. Of this mixture add 10,15 or 20 drops to a glass of wine of 3 or 4 unciae, stir with a feather or a wooden stick and let it stand until its contents are clear.

This recipe 4 was published by Eberhard Gockel (Plate 1), who was then city physician of the Imperial city of Ulm in Southern Germany (Plate 2). Gockel was the attending physician of two Ulm monasteries whose monks had drunk wines doctored by this method with the dire results which will be related below.

Litharge, which is also known as spume of silver or lead, is the solidified foam formed during the refining of lead, silver, or gold, and consists of crystalline lead oxides with a light colour. The extract prepared according to Gockel's recipe is estimated to contain $16 \mathrm{~g} / \mathrm{l}$ of lead, or considerably more than typical sapa. Added to wine at the recommended dilution, the lead content of the wine would be about 70 $\mathrm{mg} / \mathrm{l}$, which is appreciably higher than the level in Columella's wine. A second recipe given by Gockel and suitable for treating a whole cask of wine yields a somewhat lower final concentration of litharge (see Table I). ${ }^{\text {ss }}$

In 1696, the Göppingen wine-dealer from whom Gockel had obtained these recipes, was thrown by his horse and broke his neck in an accident which his fellow-citizens soon came to see as divine retribution. ${ }^{36} \mathrm{His}$ widow and son carried on the business, but, being less experienced in the art of correcting wines, merely poured the powdered litharge into the vat. ${ }^{57}$ One suspects that such empirical and non-quantitative adulteration methods for correcting wines were common. In one of them, a sack containing litharge was suspended in a barrel of wine, somewhat in the manner of a tea-bag, ${ }^{, 8}$ and as late as 1884, it was reported that in the region of Saumur, France, wine was sweetened by the addition of lead balls. ${ }^{49}$

What was possibly the least subtle of such recipes appeared, however, in two lateeighteenth-century English books, - one a cookery book, the other on winemaking: ${ }^{99,60}$ "Put a pound of melted lead in fair water, in your cask pretty warm and stop it close."

In eighteenth-century England, cider was a more popular drink than wine, but it did not offer protection against the colica Pictonum. Apart from the inadvertent lead contamination of cider, which accounted for most outbreaks of the Devonshire colic, English farmers had been known to place lead weights into casks of weak cider to improve its taste, and an English nobleman stopped the fermentation of cider by

ss 1 Württemberg Eimer $=160$ Mass $=300$ litres; 1 Mass $=40$ unciae (Untzen); 1 uncia = $47 \mathrm{ml}$ (Bassermann-Jordan, op. cit., note 33 above).

${ }^{36}$ Christian F. Sattler, Geschichte des Herzogthum's Wuerttemberg unter den Herzogen, Ulm, 1782, XII, 38; p. 82.

"7 Salomon Reisel, 'De noxa lythargyrii bismuthi in vino', Ephemerides (Misc. Curiosa), Dec. III, Ann. 5 \& 6, Obs. 261; 601-612, 1699.

s8 Christian Wollin, Von der Verfaelschung des Weins mit Bleyglaette, Altenburg, 1778.

s9 John Townsend, The universal cook, London, 1773.

$0^{\circ} \mathrm{Wm}$. Graham, Art of making wines from fruit, flowers and herbs, London, 1775. 


\section{J. Eisinger}

adding sugar of lead (lead acetate) to it. 25,30,61

And in Germany where beer was popular, a woman was discovered to be selling a recipe for keeping beer from spoiling by sweetening it with litharge. She was held responsible for an epidemic of the colica Pictonum in 1695.62

\section{THE ULM EPIDEMICS}

\section{The Political and Climatic Setting}

During the seventeenth century a number of circumstances combined to produce a series of outbreaks of the colica Pictonum in many parts of Europe. The particular epidemics which occurred in Swabia, Germany, at the end of the century offer a remarkable illustration of the intimate connexion which exists between disease and social, economic, and climatic conditions.

In the fifteenth century, wine supplanted beer as the most popular drink in Southern Germany. ${ }^{63 *}$ The sixteenth century was noted for excellent and prodigious vintages which were correspondingly cheap. In 1539 , for instance, wine was so plentiful that a barrel was worth more than its contents and in the 1420s the smallest coin, a Heller, would pay for two trips to a tavern. ${ }^{63}$

The Imperial city of Ulm, situated at the head of the navigable Danube, is not far from the Neckar valley, long famous for its wines. Beginning in the twelfth century, Ulm had become the most important shipping and trading centre in Germany: from here, Neckar wines, as well as wines from as far away as Alsace and the Rhine valley (Plate 3), were sold to Bavaria, Austria, and elsewhere. On a typical morning several hundred wagons of wine arrived at its market, many of which were sold by noon..$^{63}$

But in the seventeenth century a series of terrestrial and extra-terrestrial events threatened the prosperity and well-being of the region.

During that period, the sun underwent an unusual quiescence which had farreaching consequences on our planet: Between about A.D. 1645 and 1715, a period known as the Maunder Minimum, the number of sunspots, which generally exhibits an eleven-year periodicity, fell to almost zero. There exists considerable evidence that the resulting changes in the upper atmosphere were responsible for the coldest climate which many regions have experienced during the last thousand years. ${ }^{64.65}$

\footnotetext{
${ }^{61}$ George Baker, 'An essay concerning the cause of the endemial colic of Devonshire', Med. Trans. Coll. Phys. Lond., 1768, 1: 175-256.

62 Johann J. F. Vicarius, 'De vino lythargyriato', Ephemerides (Misc. Curiosa), Dec. III, Ann. 4, Obs. 100; 208-214, 1697.

63 Rudolf Schultze, Geschichte des Weins und der Trinkgelage, Berlin, 1867.

* In the Mediterranean area, wine had been grown and consumed since before Roman times. The Germanic tribes along the borders of the Roman Empire were introduced to wine by the dealers who customarily travelled with the Roman legions and pursued a lucrative trade with the natives. The wine sold by them was, not surprisingly, of the inferior kind, and was correspondingly heavily leaded. This may be one reason why several Germanic tribes, including the Suebi (Swabians), eventually prohibited the importation of wines (see Bassermann-Jordan, op. cit., note 33 above; Julius Caesar, De Bello Gallico, II, 15; IV, 2). Later, vineyards were planted in the regions of Germany under the Romans, but fell into decay until revived by the monks during the Middle Ages.

* John A. Eddy, 'The Maunder minimum', Science, 1975, 192: 1189-1202.

os M. Stuiver and P. D. Quay, 'Changes in atmospheric carbon-14 attributed to a variable sun', ibid., 1980, 207: 11-19.
} 


\section{Lead and wine}

At a time in which transport and communications were rudimentary, the crop failures which were caused by the severe weather commonly led to local famines, which became part of the historical record. Of other, semi-quantitative methods for reconstructing the climate of this period, the dates on which wine harvests began in each year are particularly useful. They show that the last decade of the seventeenth century produced some of the latest (and smallest) harvests which French and German vineyards have experienced.66,67 This is confirmed by records of wine prices, which similarly reflect local weather conditions (see Fig. 1, p. 292).

In Germany, the severe weather provided the backdrop for some of the most destructive warfare Europe has known. The Thirty Years' War had led to the extinction of many towns and the peasantry suffered heavily at the hands of all warring parties. In the Palatinate and the Duchy of Württemberg, the last decade of the century brought two brutal military campaigns by Louis XIV's armies, which dispersed the population, destroyed vineyards and farms, and led to the quartering of numerous troops in the towns and villages of the region.

The great demand and short supply of wine inevitably raised incentives for improving the sour vintages caused by the cold and wet weather of the $1690 \mathrm{~s}$. A weaver from Pforzheim, for example, after fleeing the war to Stuttgart, was discovered to be selling a litharge-based recipe to help vintners and dealers to sweeten and clarify their sour wines. ${ }^{36}$

This was by no means an isolated incident. Many towns in Swabia including Esslingen, Stuttgart, Heilbronn, and Giengen, were notorious for practising such adulteration. The large wine-trading centres, including Ulm, complained that the once-famous Neckar wines, which were traded there, had caused so many deaths that some of the neighbouring states had barred their sale. As a result, the sale of Württembergian wines to Bavaria ceased almost entirely. It was not resumed until 1732, when a treaty was signed which obliged Bavaria to accept a yearly 2,000 Eimer of Württemberg's wines, in return for a promise of the Duchy to fill all its salt needs in Bavaria. ${ }^{68}$

Since the wine trade constituted a major source of revenue of the Duchy of Württemberg, its sovereign, Duke Eberhard Ludwig took a lively interest in the controversies surrounding the practice of "correcting" wines. Some physicians advocated the use of litharge for this purpose, while others warned against it. Johann Matthäus Bruegel, for instance, had stated that the ingestion of litharge had no bad consequences and, since he was the town physician of Heidenheim and had the reputation of being a learned man, his views contributed to the spread of litharge-treated wines. The town physician of Göppingen was also of the opinion that litharge was an innocuous additive. It is noteworthy that he and Bruegel served in two important wine-producing localities, while Gockel lived and worked in Ulm, the largest wine-trading centre in Germany. ${ }^{56,69}$

\footnotetext{
66 Emmanuel Le Roy Ladurie, Times of feast times or famine: a history of climate since the year 1000, trans. by B. Bray, London, Allen \& Unwin, 1971.

${ }^{67}$ K. Müller, Geschichte des Badischen Weinbaus, Lahr-in-Baden, 1953.

* Bassermann-Jordan, op. cit., note 33 above, vol. 2, p. 1114.

o J. Dornfeld, Die Geschichte des Weinbaues in Schwaben, Stuttgart, 1858.
} 

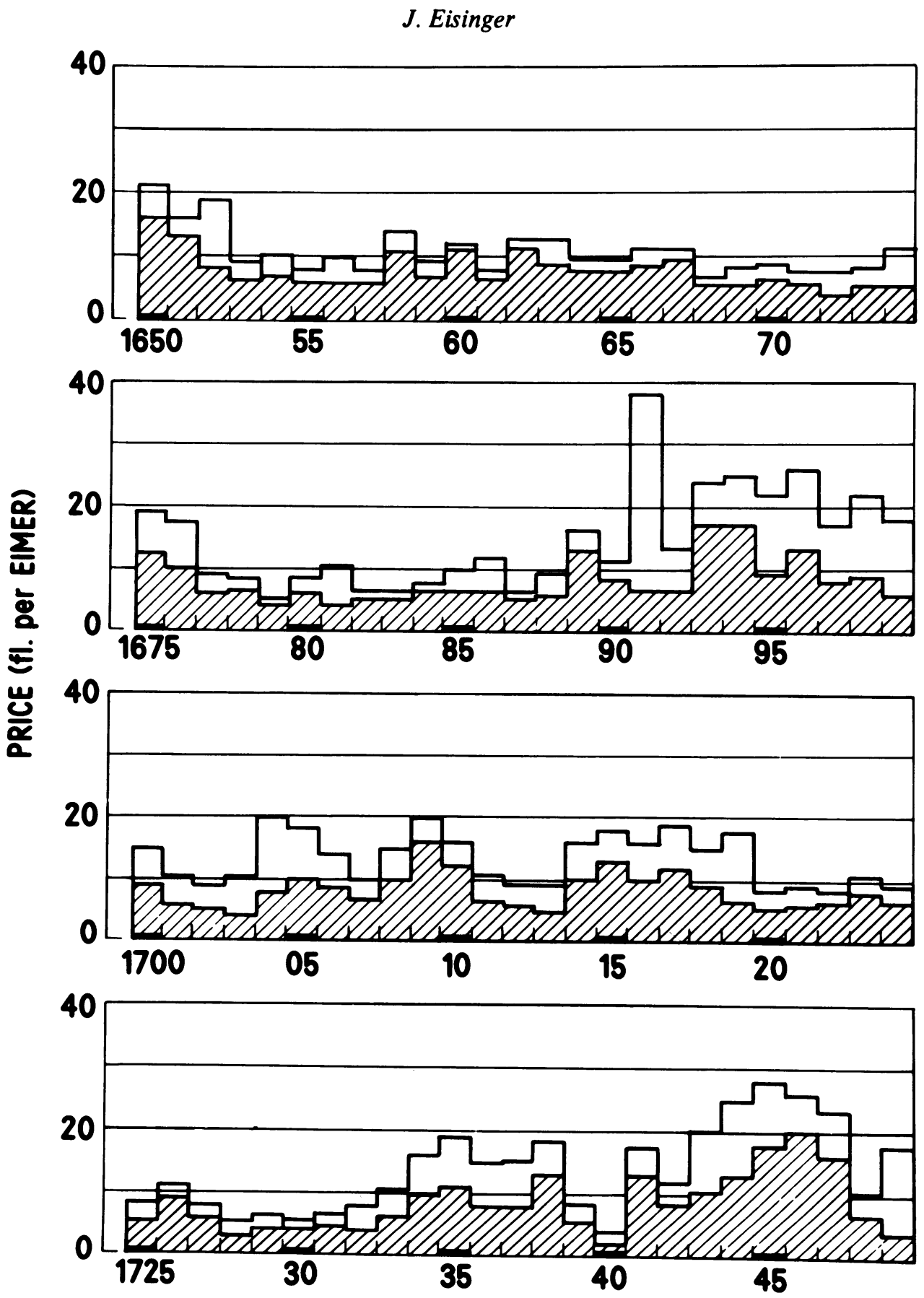

Figure 1. The two histograms display the lowest and highest prices at which wine was sold in Württemberg. ${ }^{33}$ The minimum price provides a good measure of the size and quality of the grape harvest and of the magnitude of the demand for wine. It can be seen that for the years immediately preceding those of the Ulm epidemics of 1694-96, this price was among the highest of the century. 


\section{Lead and wine}

In 1696, the duke asked his two court physicians, Salomon Reisel and Johann Caspar Haerlin, for advice in this matter. These two eminent doctors were familiar with Gockel's investigation into the cause of the two outbreaks of the colica Pictonum in Ulm and were therefore aware of the dangers of litharge-treated wines. Their advice prompted the duke to issue an edict to deal with the problem, which will be discussed below.

\section{Biographical Sketch of Eberhard Gockel}

Eberhard Gockel's grandfather, Balthasar Gockel, came to Ulm as a boy in 1596. His stepfather had intended him to become a butcher and had sent him to the city to learn arithmetic. Once there, the boy developed a taste for learning and he eventually had a distinguished career in the Church.

His son, Eberhard's father, Johann Georg Gockel, at first also pursued an ecclesiastical calling, but gave it up to study medicine and served as "Stadt Physicus" in Ulm during the Thirty Years' War. During that period, he encountered epidemics of the colica Pictonum and exchanged correspondence about them with a fellowphysician, which was eventually published by his son, ${ }^{29}$ and suggests that Eberhard Gockel was familiar with the disease well before the Ulm epidemics.

Johann Georg Gockel's wife was Maria Eberhardina, who bore Eberhard on 13 June 1636. At sixteen, after finishing his schooling in Ulm, Eberhard Gockel went to Tübingen to study medicine, and eventually to Basle for further training. He received his doctorate there in 1656, and in the same year he was appointed physician in Waiblingen. Five years later, he became Physicus of Geisslingen and then of Giengen. In 1675 , he was appointed City physician of Ulm, as well as attendant physician to at least five monasteries in and near the town.

He married Maria Barbara Ruoff, the daughter of a distinguished doctor, in 1656, and they had eighteen children: seven boys and eleven girls.

Eberhard Gockel was an industrious and learned medical man and was much honoured in his home town. He died of a contagious fever in Ulm in 1703. One of his sons, Christopher Erasmus Gockel, also practised medicine in Ulm, but died on the same day as his father, when he was only forty-one. ${ }^{29}$

Gockel was a prolific author and published about a hundred books, tracts, and articles in medical and scientific journals, but none of his works appears to approach his treatise on the Ulm epidemics in originality or importance. His writings reveal his common sense and his considerable breadth of knowledge and interest, and are at times marked by rambling loquaciousness and extraordinary gullibility. Although his approach to medicine was often empirical, it is hard to think of Gockel as a man of the Enlightenment, for he was prey to numerous medieval superstitions. He wrote a book about the diseases caused by ire, ${ }^{10}$ and another about the illnesses caused by magic and spells. The latter presents accounts of encounters with witches and werewolves, how to recognize their medical consequences and how to cure them. ${ }^{11}$ Gockel's most bizarre

\footnotetext{
${ }^{70}$ Eberhard Gockel, Discursus politico-historico-medicus de ira, Leipzig and Halle, 1668.

${ }^{71}$ Eberhard Gockel, Tractatus polyhystoricus magico-medicus curiosus, oder ein kurtzer ... Bericht von dem Beschreyen und Verzaubern ... , Frankfurt and Leipzig, 1717.
} 


\section{J. Eisinger}

treatise deals with a rooster who had reputedly laid an egg. ${ }^{22}$ It was published in the same year as his work on the colica Pictonum and contains a string of unrelated mythological, biblical, and factual stories dealing with either chickens or eggs. The book also presents a careful description and analysis of the pear-shaped egg, which had purportedly been laid by a local rooster. It is dedicated to Count Frantz Sigmund Joseph von Fugger, a member of the rich and powerful banking family from Augsburg. Gockel's motivation for writing this book is probably explained by this dedication, for the marvellous rooster belonged to the count and the rooster's egg had been brought to Gockel, who was probably considered the most learned man in the vicinity, on the duke's orders.

\section{Gockel and his Patients}

In 1694, the colica Pictonum had broken out in two Ulm monasteries under Gockel's care. Gockel was then a man of fifty-eight and had had forty years of experience as a physician. Two years later he published a medical paper which was entitled, appropriately enough, "About the sweetening of acid wine with litharge with the greatest harm to those who drink it".s4 The paper does not confine itself to the purely medical aspects of the disease, and it is clear that its author was well aware of the combination of circumstances which had brought on the recent epidemics in the vicinity of Ulm, for it begins with these remarks:

In 1694, 95 and 96, when the well known and noble Neckar wines of earlier years were either looted by the rapacious French [gallos] or, partly indeed, consumed by natives and by strangers and when, for several years, acid, rough and sour wines filled their places and therefore were rejected by many and found few buyers, some dealers and shippers in order to accommodate their wines to people's palates, corrected, as they thought, the acid wines with certain seasonings made from litharge, . . . so that they could be sold at a higher price like superior, pure wine.

Gockel's recipe for achieving this is given earlier. Being a practical man, Gockel tested this recipe on the "worst and sourest wine" which he could find, and reported"3 that within a few minutes he had converted it into "the best and loveliest wine"!" This judgment of Gockel's is borne out by numerous other reports, including modern ones, which attest to the fact that lead can indeed improve the flavour of wines. ${ }^{74}$ Gockel also recorded that wine, corrected in this manner, retains its "süsselechtenlieblichen" (sweetish-lovely) taste for no more than three or four months.

To detect this fraud, Gockel offered the first practical assay for testing wine suspected of containing lead. The test calls for the addition of 10-12 drops of sulphuric acid (oleum vitrioli) to a 3- or 4-ounce glass of wine and watching for the

72 Eberhard Gockel, Der eyerlegende Hahn ..., Ulm, 1697.

${ }^{73}$ The taste of food, as well as wine, has been reported to be enhanced by lead. In a certain English village the currant tarts baked in a particular pottery form (and glazed with a cracked lead glaze) had been found to be especially tasty and to require the least amount of sugar - still a luxury for most people in the eighteenth century (Baker, op. cit., note 23 above). The "peculiarly agreeable flavour" of meats broiled on hot "pigs" [ingots] of lead is also mentioned by Thomas Percival, who reports, that this method of cooking was popular in the vicinities of English lead smelters in the eighteenth century (Percival, op. cit., note 41 above).

${ }^{14}$ (a) T. P. Whitehead and A. P. Prior, 'Lead poisoning from home-made wine', Lancet, 1960, ii: 1343-1344. (b) C. R. Lane and A. Lawrence, 'Home-made wine as a cause of lead-poisoning: report of a case', Br. med. J., 1961, ii: 939-940. 


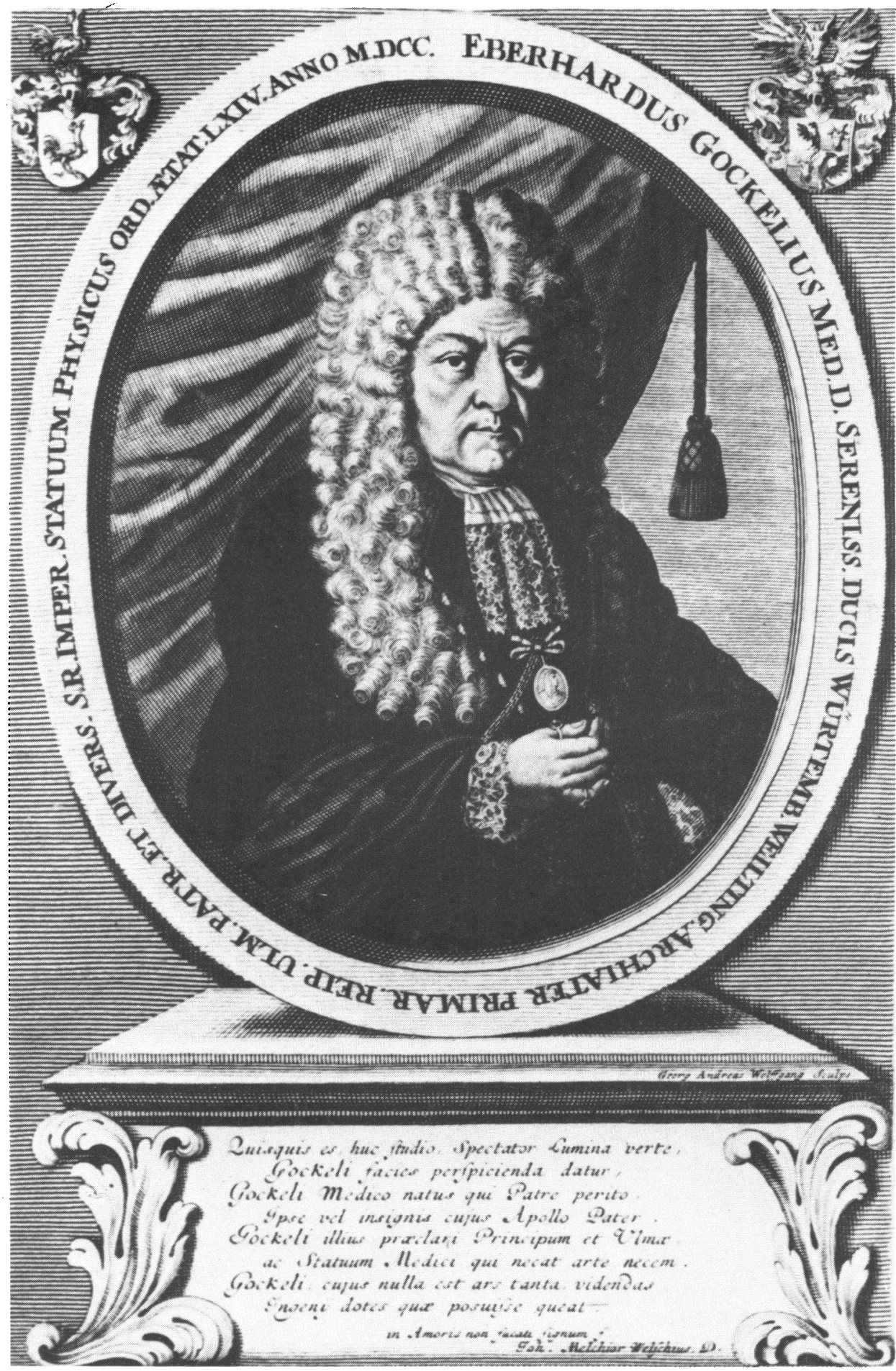

Plate 1. Contemporary portrait of Eberhard Gockel, aged sixty-four, by Georg A. Wolffgang the elder $(1631-1716)$. 

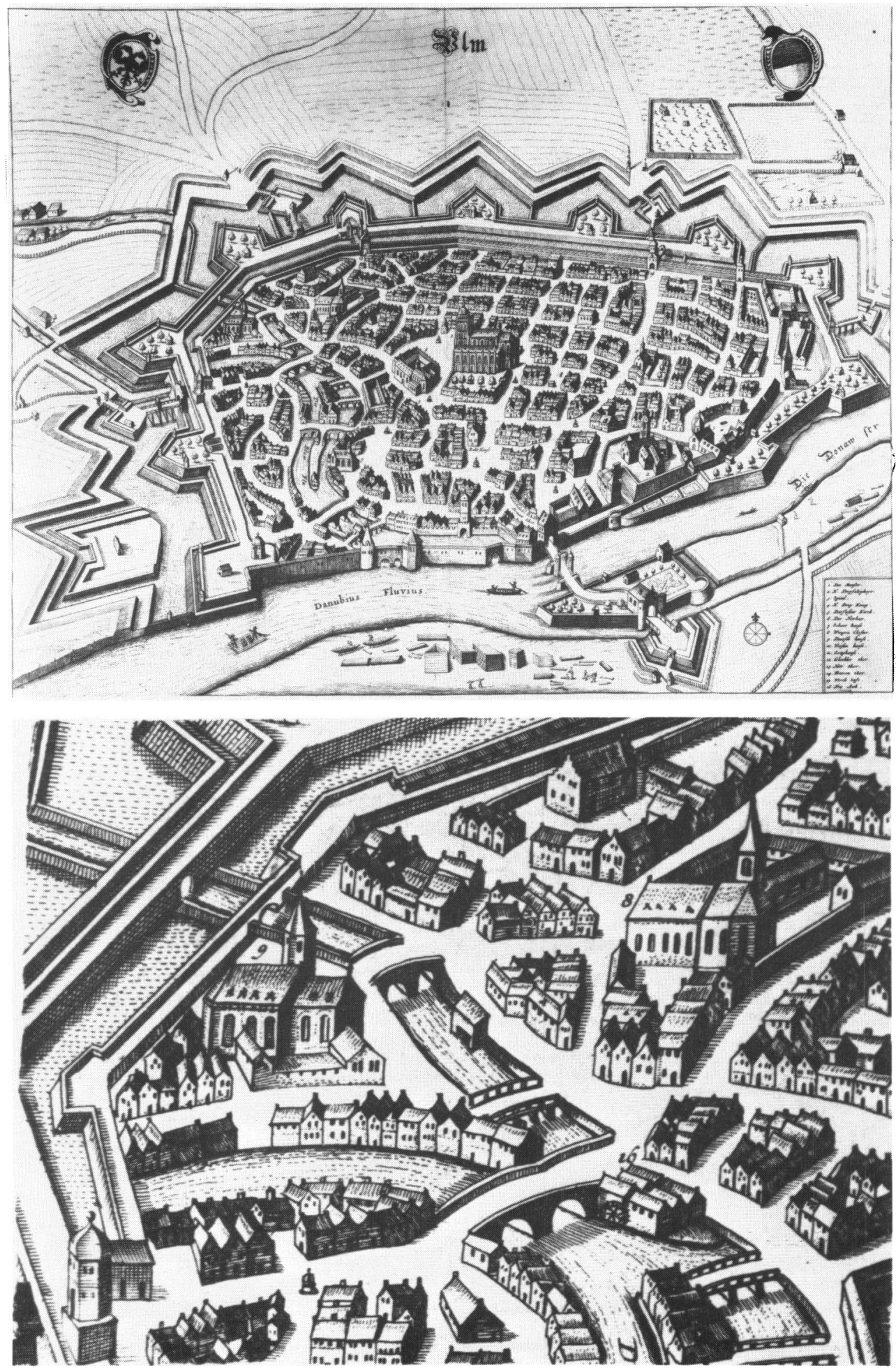

Plate 2. (a) View of the city of Ulm in the middle of the seventeenth century (Frederick de Wit, Theatrum praecipiarum totius Europa . . . , Amsterdam, 1693-1700). (b) Enlarged portion of (a), showing the "Teutsches Haus" [8] and the Wengen monastery [9], where Gockel's patients lived. 


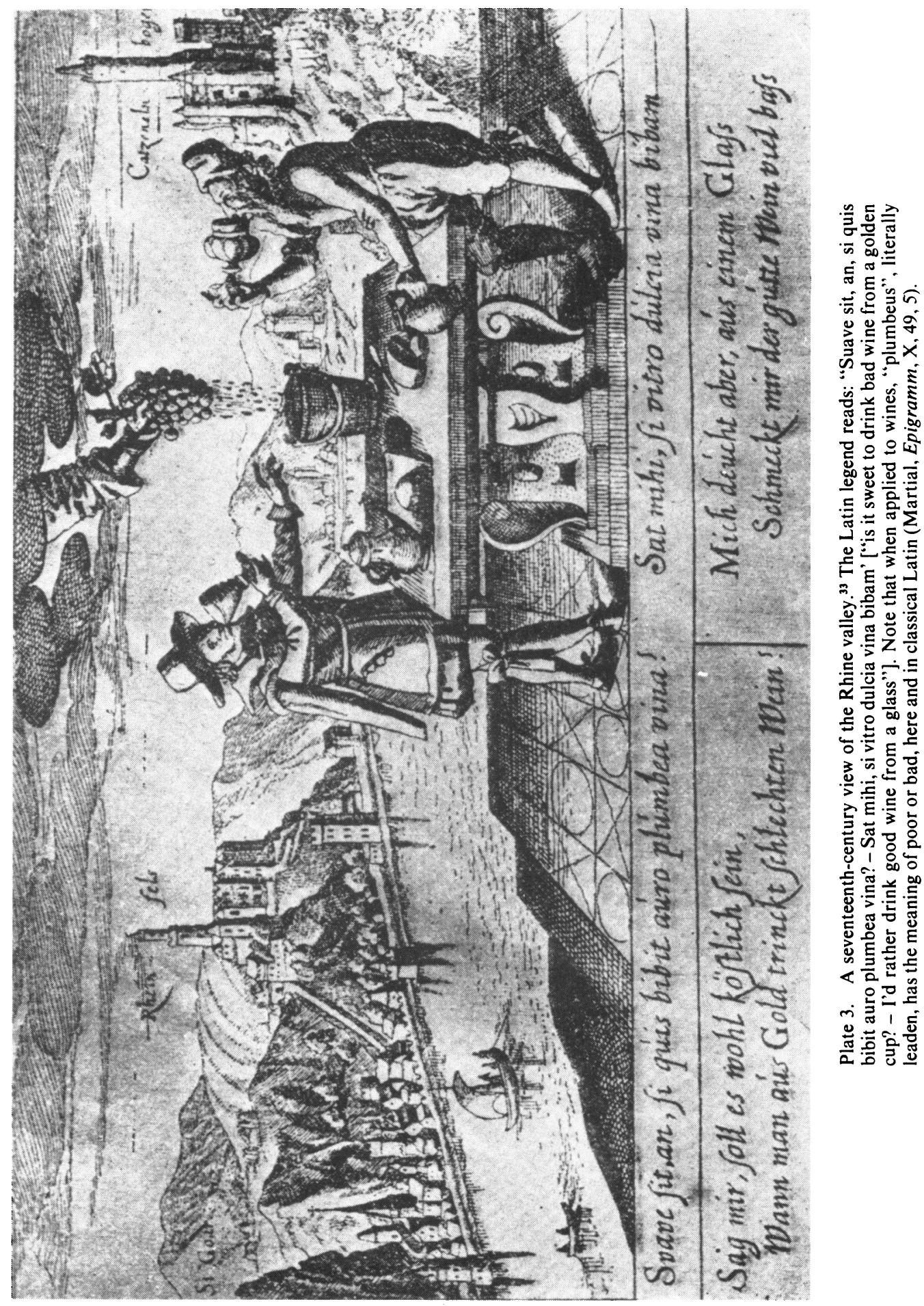




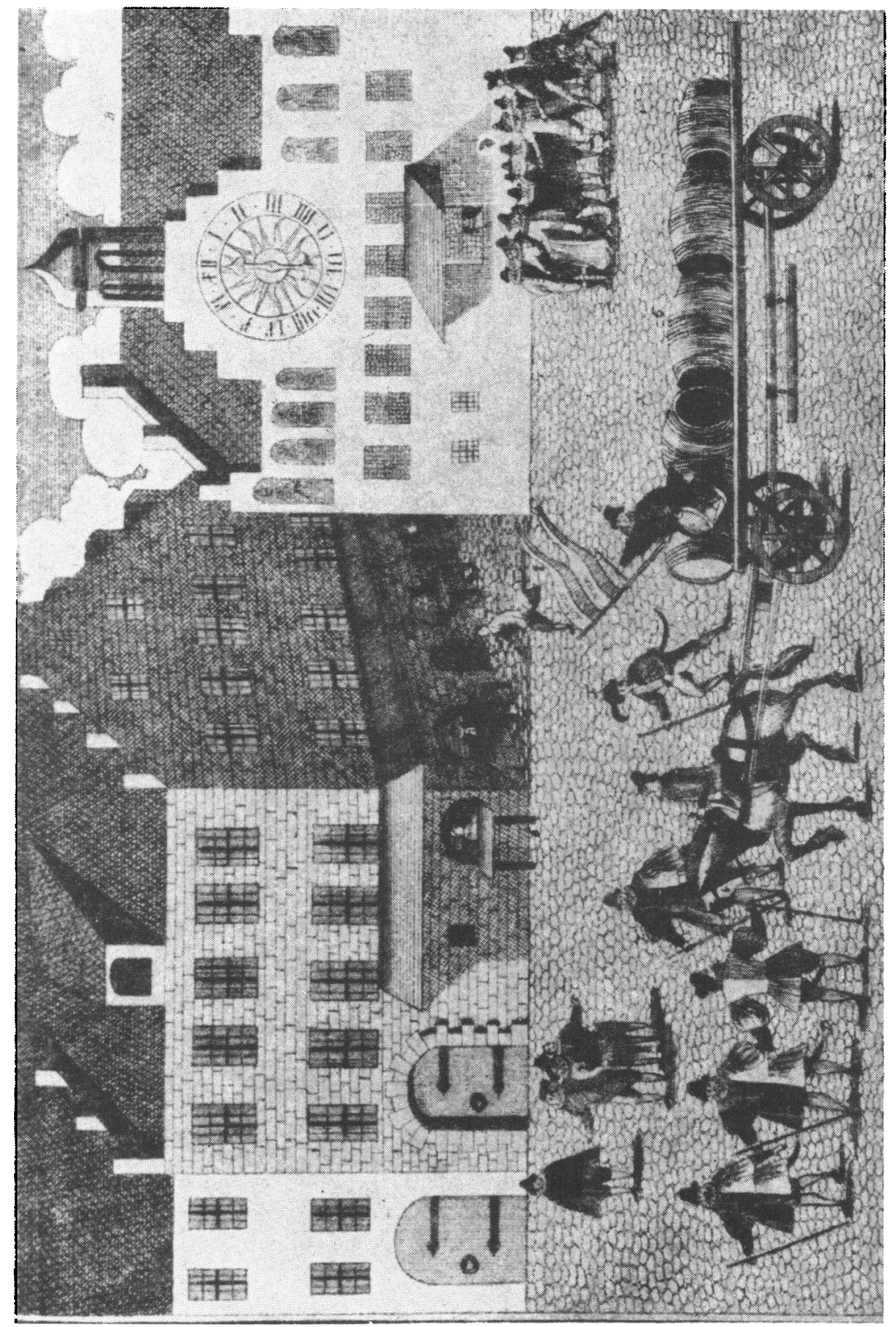

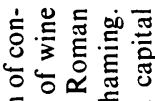

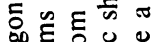

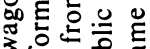

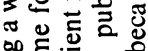

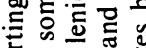

항증

过

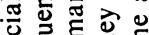
䢛

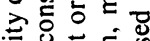
论

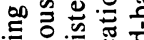

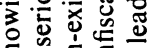
宓施

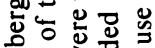

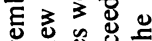

닐

$z \equiv 3 \geq s$

탕

는

.

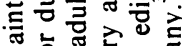
은은 일 ठั.

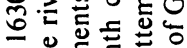


응. 홀

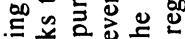

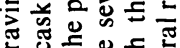

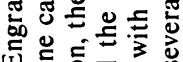

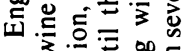

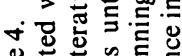

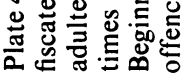




\section{Lead and wine}

appearance of a white precipitate (lead sulphate). When this assay was recently tested on wines to which various amounts of lead acetate had been added, it was possible to detect a concentration of about $10 \mathrm{mg} / 1$. The assay was therefore sufficiently sensitive to detect lead in wines treated according to the Göppingen recipe given above. ${ }^{75}$

Besides the medical paper in Latin discussed here, Gockel also wrote a "popular account" in German about the Ulm outbreaks. "It is an expanded version of the Latin paper and in it, Gockel expressed his ardent admiration for Samuel Stockhausen, a man who could rightfully be considered the first occupational physician. For it was Stockhausen's work" ${ }^{76}$ which convinced Gockel, and, as he put it, "anyone with understanding", that the illness of persons who had taken litharge internally was identical with that then raging in many parts of Swabia, ${ }^{17}$ which, he said, was usually caused by adulterated wines." Gockel referred to Stockhausen as "sharp-minded" (scharfsinnig) and considered his tract on the "Hüttenkatze", the ancient scourge of miners, to be "extraordinary".

Stockhausen's little book, which had appeared fifty years earlier and is apparently his only published work, had indeed shown for the first time that exposure to lead, and to lead alone, produced the symptoms of the Hüttenkatze. Before that, all mining had been considered a generally unhealthy and dangerous occupation, but the symptoms of chronic lead poisoning had not been identified among the many ills which had beset miners since ancient times. The whole syndrome was called morbi metallici by Roman and medieval authors alike. ${ }^{78}$ The life expectancy of miners was indeed so poor, that from Classical times to the Middle Ages, lead was usually mined by slaves, prisoners of war, and convicts. ${ }^{48,79}$

In an approach which differed little from that of modern occupational medicine, Stockhausen had observed miners, smelter-workers, and potters (who employed lead glazes) at their tasks and had noted that only those workers who were exposed to lead fumes or dust developed the symptoms of the Hüttenkatze. ${ }^{76}$ The symptoms are unmistakably the same as those of Gockel's patients in the two monasteries in Ulm.

\footnotetext{
75 Alison Eisinger, Jorge Flores, and Josef Eisinger, unpublished observations, 1979.

${ }^{76}$ Samuel Stockhausen, Libellus de lithargyrii fumo noxio morbicifo, metallico frequentiori morbo vulgo dicto Die Huettenkatze, Goslar, 1656.

$"$ These included the towns or monasteries of Schwäbisch Gmünd, Mindelheim, Wettenhausen, Roggenburg, Ursperg, Weissenhorn, Wiplingen, Babenhausen, Kehlmüntz, Erbach, Weissenstein, and Grünebach, all places where litharge-treated wines had caused "long and unbearable suffering" according to Gockel. Another physician, who had been invited to append a section to Gockel's book, reports similar outbreaks of the colica Pictonum in Baden and in Moravia and remarks that these were particularly severe among the peasant population and among heavy drinkers.

It is interesting that the title of Gockel's book refers to the "Wein-Kranckheit" (wine-disease) as being a new and previously unheard-of disease. This was clearly not the case, and no such claim is made by Gockel in his Latin report addressed to the medical profession (Gockel, op. cit., note 54 above).

Medical books in German were rare at this time. They were deplored by Stockhausen, since they made medical information available to unqualified and unscrupulous medical practitioners. Stockhausen therefore wrote his tract in Latin. He realized, however, the importance of disseminating his findings beyond the medical community, and therefore appended a summary of his conclusions, written in German and addressed to the mining engineers of the Goslar mines (Stockhausen, op. cit., note 76 above).

$n$ [-] Koelsch, 'Samuel Stockhausens Schrift über die “Hüttenkatze” (1656)', Zbl. Gewerbehyg., 1924, 41-43, 76-77, 101-103.

7 Josef Eisinger, 'Lead and Man', Trends in biochem. Sci., 2: N147-N150.
} 


\section{J. Eisinger}

Gockel's monastic patients included several eminent persons, including Count Franz Ludwig Leibelfingen, prelate of the Teutonic Order of Knights in Ulm (Deutschorden Haus or Teutsches Haus). The Count, the order's secretary, chaplain, and the chaplain's personal servant all suffered the classical, cruel symptoms of the disease and died several months after contracting it during the Christmas holidays in 1694. At the time of their deaths, ${ }^{\infty 0}$ the cause of the outbreak was still a mystery, and Gockel could suggest no cause in his first brief account of the case. ${ }^{81}$

This short paper, written in 1695 but published after his full account of the "wine disease" had appeared in 1697,4 reveals Gockel as he is beginning to question the then generally accepted "humoral" theory of the colica convulsiva. He noted that his patients in the Wengen monastery had all developed similar symptoms at about the same time, even though their constitutions had been of very different natures. Gockel already suspected instead that the disease had been caused by an external cause "hostile to the nerves" and possibly by "some poison craftily inserted in food, wine or water", but litharge is not mentioned.

The fact that several persons who lived and ate together at the Deutschorden Haus had fallen ill at the same time, had also aroused the suspicions of Count von Leibelfingen, and the dying prelate had ordered that the two wells of the monastery should be emptied and examined. Gockel checked the wells and kitchen to no avail. His suspicions turned, however, to the monastery's cellar when it was pointed out to him that two or three visiting Franciscan Fathers from Ehingen, who had come to the Teutsche Haus to conduct masses, had also contracted the colic of Poitou after sharing their hosts' wine for a few days. They had, however, recovered completely after returning to their own monastery..$^{34,4}$

Gockel's most important observation was, however, that all those monks who had not drunk the wine had not contracted the disease.

What may have helped Gockel in his investigation as much as his powers of observation, was his conscientious attendance on his patients: for he visited the colic victims in the monastery daily and occasionally in the evening as well, and on each occasion he was offered a glass of wine by his monastic hosts. He related that, since he did not yet suspect the wine, "he did not escape unharmed but a little later, was attacked by the most atrocious colic pains and a terrible fever, which did not leave me for half a year." This experience not only sharpened his desire to discover the true aetiology of the disease, but provided him with a valuable clue. ${ }^{34}$

A visit to the wine-cellar confirmed Gockel's suspicion. On examining the inside of the vat which had contained the wine consumed by his patients, he found that it contained a viscous and sticky sediment. The wine had been sold by the dealer from nearby Göppingen, from whom Gockel eventually obtained the recipe given above.

\footnotetext{
" The Augustinian monks in the Wengen Kloster, the other Ulm monastery under Gockel's care, fared relatively better. None died in the 1695 epidemic, but almost all suffered serious symptoms, including weakness and paralysis of the extremities. The monastery's prelate was again among the victims. His name was Count Augustin Erath von Erathsberg, and he remained paralysed until his death in 1736. Gockel dedicated his book on the "wine disease" to him (op. cit., note 4 above).

"1 Eberhard Gockel, 'Colica spasmodica \& convulsiva ...', Gallicinium medico practicum s. consiliorum observationum ..., Obs. med. 86, Ulm, 1700 (written five years earlier, when the chaplain's servant, who died in 1696, was still alive).
} 


\section{Lead and wine}

\section{After the Ulm Epidemics}

The wine epidemics in and around Ulm had stimulated several other Württemberg physicians to search for their cause, and their findings confirmed Gockel's conclusions. ${ }^{57,30,82}$ One doctor even conducted a crude animal experiment in which a dog was poisoned by litharge, but his report fails to specify the lethal dosage. ${ }^{83}$ Another physician described a colic epidemic, whose by now familiar symptoms had been brought on by the consumption of leaded beer. ${ }^{30}$

The accumulated evidence was reviewed by Salomon Reisel, the duke's personal physician, and became the basis of the edict which Duke Eberhard Ludwig issued against adulterating wines with litharge. The law not only prescribed "loss of life, honour and fortune" for dealers who treated wines with litharge, but also for anyone who failed to report offenders to the authorities. ${ }^{44}$ The decree was dated 10 March 1696 , even before the publication of Gockel's book.

Duke Eberhard Ludwig also ordered that a report detailing the danger of lead additives should be sent to all doctors in Württemberg and the neighbouring states. Three years later, Reisel complained, however, that this report was suppressed and was never published, because "talk about litharge-treated wines had ceased" and it was feared that such publicity would ruin sales of Neckar wines. ${ }^{57}$

The practice may itself have receded, possibly because of improved vintages, but it certainly had not ceased: Only a few years later, it was deemed necessary to set an example to persistent offenders, and Johann Ehrni, a cooper from Esslingen, was tried and found guilty of correcting his wines with litharge, and was publicly beheaded in Stuttgart. ${ }^{.66}$

\section{Legislation}

Duke Eberhard Ludwig's edict, apparently the first directed specifically against leaded wines, was by no means the first to deal with wine adulteration: the earliest one is said to have been promulgated by Charlemagne in 802.69

In Ulm, the adulteration of wines had been a problem long before Gockel's time, for in 1487 the city had passed a law which required every innkeeper to swear that his wines were pure and that neither he, nor his wife or servants, had added any of a list of adulterants which included "Bleiweiss" (lead oxide). ${ }^{69}$ An imperial edict of 1497, while forbidding various wine additives including lime, milk, and ceruse (lead carbonate), was intended to cope with the frequent outbreaks of fatal disease in Germany, which had, in many cases, been traced to wines. The symptoms were said to include abortions and subsequent sterility among pregnant women - classical symptoms of chronic lead poisoning..$^{85}$

There was, in fact, a constant stream of legislation against wine adulteration in Germany (and elsewhere) throughout the Middle Ages. ${ }^{69,33}$ The frequency with which

\footnotetext{
22 Rud. Jac. Camerarius, Disputatio de colica-epileptica, Württemberg, 1698.

*3 Joh. Conrad Brunner, 'De experimento circa noxam lithargyrii', Ephemerides (Misc. Curiosa), Dec. 3, ann. 4, obs. 92, 1697.

थ4 Edict by Duke Eberhard Ludwig of Württemberg, 10 March 1695, Bestand A39, Bü. 15, Hauptstaatsarchiv, Stuttgart.

ss Johann Philipp Datt, Volumen rerum Germanicarum novum, lib. 3, ch. 14, 630-639, Ulm, 1693.
} 


\section{J. Eisinger}

these laws had to be renewed and the penalties raised testifies to the difficulties encountered in enforcing them. This was probably due to uncertainty as to the active ingredient used by the wine adulterers and to the lack of any reliable assay for suspected wines. For lead was only one among the pharmacopoeia at the disposal of the wine adulterers, which included lime, mercury, arsenic, sulphur, bacon, mustard, and other spices and herbs. The continued medicinal use of lead compounds certainly contributed to the popular acceptance of lead additives as benign.

The penalties for "correcting" wines were, moreover, surprisingly lenient: in fifteenth-century Germany, offenders were generally punished by money fines and public shaming, while the casks of adulterated wines were emptied into the river (Plate 4). ${ }^{33}$ The Thirty Years' War destroyed the fabric of German society so thoroughly, that even these laws were widely flouted and forgotten by many.

By the eighteenth century, analytical chemistry was making important strides and numerous chemical procedures for determining the lead content of wines were published. More important, they were increasingly specific and sensitive, ${ }^{58.23}$ and undoubtedly played an important part in deterring abuse. In the 1750s, several German cities and states (e.g. Trier, Hesse, The Palatinate, Baden) followed Württemberg's precedent and issued laws which specifically forbade the use of litharge as a wine additive and which prescribed stiff penalties, including prison and death, for perpetrators of this fraud..$^{33}$

This was also the century in which sugar and distilled spirits became cheaper and readily available, and eroded the economic motive for correcting wine in the ancient manner. When the wines of Michael Körner, a dealer from Esslingen, came under suspicion in 1745, he was let off with a warning; for he could prove that his wines had only been adjusted with cream of tartar, sugar, and fresh well-water.69 The colic of Poitou nevertheless remained a common and deadly disease through most of the eighteenth century, ${ }^{23}$ and even in 1820 the lead content of some fortified wines was high enough to suggest that the taste for sapa had not disappeared entirely. ${ }^{86,87}$

\footnotetext{
* The presence of modest levels of lead in fortified wines, particularly in port, has been suggested as a likely explanation of the gout epidemic which afflicted many well-to-do Englishmen during the eighteenth and nineteenth centuries. During this period, the shipments of port to England reached 5 million gallons in 1825 (W. S. C. Copeman, A short history of the gout and the rheumatic diseases, Berkeley, University of California Press, 1964).

Alfred Garrod, who was the most important contemporary student of the disease, noted that fortified wines were especially potent inducers of gout and that it was a rare illness in other Northern European countries, where such wines were rarely consumed, and that it was equally rare among English whisky drinkers (Ball, op. cit., note 87 below; A. B. Garrod, The nature and treatment of gout and rheumatism, London, 1859).

Gout is the result of hyperurecaemia, the accumulation of uric-acid in the serum. This condition may be brought on by a genetic enzyme deficiency or by the excessive intake of foods rich in purines, which are broken down to uric acid. It can, however, also be the result of impaired clearance of uric acid by the kidneys. The high incidence of gout among painters and other lead-exposed workers was noted by Garrod, and has also been well documented among habitual drinkers of moonshine whiskey (G. V. Ball and L. B. Sorensen, 'Pathogenesis of hyperurecemia in saturnine gout', New Engl. J. Med., 1969, 280: 1190-1202). Such whiskeys frequently contain lead levels of the order of $1 \mathrm{mg} / \mathrm{l}$ (Ball, op. cit., note 87 below), probably because heavily soldered automobile radiators are sometimes used as condensers in illegal stills in the Southern United States. Saturnine gout may occur in the absence of the classical symptoms of the colica Pictonum, and is among the manifestations of chronic lead disease.

" G. V. Ball, 'Two epidemics of gout', Bull. Hist. Med., 1971, 45: 401-408.
} 


\section{Lead and wine}

\section{EPILOGUE}

Lead is one of the first metals which man learned to refine. The oldest lead objects found by archaeologists includes a string of lead and copper beads worn in Anatolia some 8,000 years ago. ${ }^{88}$ Since lead is abundant, malleable, and easily refined, the metal was soon put to innumerable other uses, and its oxides have been employed as pigments since antiquity. We do not know when the ability of lead to sweeten and preserve wines was discovered, but it is clear that it took many centuries before the profound harm which ensued from this apparently useful discovery was appreciated.

Why was it so long before the colica Pictonum was recognized as lead disease and why was Gockel's inquiry finally successful? To understand the long history of the disease it is well to recall, that the most useful clue connecting the colica Pictonum to long-term, low-level lead intake is provided by the identity of symptoms exhibited by victims of the disease on the one hand, and those of lead-exposed workers, particularly miners, on the other. Both of these groups were numerous for many centuries, but, although classical authors from Nicander (second century B.C.) on, knew lead to be an acute lethal poison, the danger of chronic lead ingestion was never appreciated, ${ }^{89}$ and the symptoms of chronic lead disease were never described. ${ }^{10,31}$ As long as lead mining and smelting operations were performed by expendable members of society, who were rarely, if ever, attended by doctors, the syndrome of symptoms of chronic plumbism remained hidden. ${ }^{90,50}$ Only during the Renaissance did the health of miners become a matter of public concern, and then for economic, as much as for humanitarian, reasons. This concern prompted the enlightened dukes of Lower Saxony to create the office of "Bergmedicus" (mine physician) for the important lead and silver mines near Goslar, which are, incidentally, productive to this day. ${ }^{91}$ Samuel Stockhausen was one of the first doctors appointed to this post (1651). Not only was his work on the Hüttenkatze of great value to miners, but his little book provided an important key for Gockel's discovery: for Gockel probably never saw a miner suffering from Hüttenkatze, and Stockhausen lived in the beer-drinking north, where the "wine disease" was rare.

Eberhard Gockel's insight that a common, external agent had made his monastic patients ill, was, of course, crucial. He was aided in arriving at this conclusion by dealing with a well-defined epidemiological group, whose wine had, morever, been laced with an unusually high concentration of litharge (c.f. Table I), so that several victims had contracted the disease almost simultaneously. It is likely that many similar epidemic outbreaks, for instance those caused by leaded wines served in taverns, went undetected.

To appreciate the great advance in medical understanding which Gockel's work represents, one should remember that in his time, there was nothing unusual about a disease whose aetiology was unknown: theoretical causes, such as those based on the patient's "humours", satisfied most physicians, if not their patients. Indeed, Gockel's

\footnotetext{
* J. Mellaart, Catal. Hüyük: a neolithic town in Anatolia, London, Thames \& Hudson, 1967.

" Poisoners, on the other hand, made use of the cumulative character of lead poisoning since ancient times (Stevenson, op. cit., note 31 above).

* George Rosen, The history of miners' diseases, New York, Schuman, 1943.

1 Wilhelm Bornhardt, Geschichte des Rammelberger Bergbaues, Berlin, 1931.
} 


\section{J. Eisinger}

contemporaries, and some of his successors as well, saw the colica Pictonum not so much as a disease, but as a condition which could be brought on by a variety of "remote causes". This can be seen, for instance, from the following list of such causes which was compiled by Theodor Tronchin during the eighteenth century, well after Gockel. ${ }^{17}$

First. To the remains of fevers carried off by an imperfect crisis, or not well cured.

Secondly. To poisons.

Thirdly. To the too free use of wine, or of acid-austere fermented liquors, or of unripe acid fruits.

Fourthly. To the gout or rheumatism.

Fifthly. To an obstructed perspiration.

Sixthly. To the scurvy.

Seventhly. To melancholy.

Eighthly, and Lastly. To the passions of the mind.

Tronchin devotes a chapter to each remote cause and, while the one on poisons clearly implicates lead in many of the case histories, its dominant role is not appreciated.92 Similar lists of remote causes of the colica Pictonum had appeared elsewhere $e^{38}$ and were eventually rebutted, point by point, in a scathing analysis by the brilliant English physician, Sir George Baker, who, as the discoverer of the aetiology of the Devonshire colic, was in many ways Gockel's English counterpart. ${ }^{93.94}$

Why did it take so long for Gockel's findings to be accepted? The suppression of the medical report which identifies leaded wines as the cause of the Württemberg epidemics (see above), shows that the wine-producing states feared economic disruption and financial losses if the dangers of treating wines with litharge were exposed and publicized. But the dissemination of Gockel's findings was impeded not only by such commercial considerations, but also by the poor communications among physicians. This was aggravated by the fact that Eberhard Gockel was almost unknown outside Swabia and was not associated with any of the famous medical schools. In fact, the first treatise about the colica Pictonum which subscribed unequivocally to Gockel's findings was written by George Baker, seventy years after Gockel's book was published. ${ }^{10.30} \mathrm{It}$ is in contrast with many other eighteenth-century publications which ignored Gockel's work and continued to consider the colica Pictonum as arising from various possible origins. ${ }^{95.96}$

The clinical signs and symptoms of chronic lead disease were eventually described in detail by Tanquerel des Planches in $1838 ;^{5}$ but even after that, medical circles were

\footnotetext{
92 Tronchin even praised the work of the Württemberg physicians, including Gockel, and deplored the adulteration of wines by "roguish vintners", but failed to mention lead as the adulterant! He noted, however, that many painters, including Raphael and Correggio, had succumed to the colico Pictonum, as had potters, "metallurgists", and others exposed to lead.

${ }_{93}$ The publication of Baker's findings provoked a storm of protest from the apple-growing West Country. Several doctors published tracts to refute his hypothesis and his elegant experiments, and Baker, himself a Devonian, was personally villified (Waldron, op. cit., note 25 above).

94 George Baker, 'An examination of the several causes, to which the colic of Poitou has been attributed', Med. Trans. Coll. Phys. Lond., 1768, 1: 364-406.

9s Niels Seerup, Triumphus lithargyriatorum, Diss. med. var. arg., Copenhagen, 1700, 65 (18), 1-50. Seerup denied that the ingestion of lead was harmful.

* Philippe Grandjean, 'Lead in Danes, historical and toxicological studies', in F. Coulston and F. Korte (editors), Environmental quality and safety, New York. Academic Press, 1975, suppl. vol. 2, pp. 6-75.
} 


\section{Lead and wine}

slow to appreciate the dangers of chronic lead exposure, and chronic lead disease, then usually not related to wines but to occupational exposure, ${ }^{97.98}$ was apt to remain undiagnosed until the end of the century. ${ }^{31}$

The long persistence of the colica Pictonum was as disturbing and puzzling to the analytical mind of Baker, as it appears today. He seems to sum up the whole disaster, and, for that matter, the problem of environmental intoxicants in general, when he writes: $^{23}$

Here then is a remarkable instance of a most insidious poison, taking as it were advantage of our necessities, and recommending itself to us by means of a quality, which at once favours economy, gratifies the palate and may lay the foundation to a painful, lingering disease, more formidable than death.

\section{APPENDIX}

In 1639, Francis Citois, then the personal physician of Cardinal Richelieu, viewed the colica Pictonum, like many other authors on the subject, as a new disease, which had appeared in 1572 in Poitou, the region in Western France situated roughly between Poitiers and the Atlantic coast. After raging in the region for sixty or seventy years, it became milder and less intractable, but emerged in various other parts of France. Citois notes that its appearance in Poitou coincided with the appearance of a new star in the Constellation Cassiopeia, and that similar new diseases (lues venerea, sudor anglicus, plica polonica) had lately been used as instruments of God's vengeance on a sinful world. ${ }^{99}$ Citois left this vivid account of the symptoms of the disease: 100

A new colic disease named 'bilious' for the most bitter pains from the bile (as it is believed) has arisen
and is even now spreading. ... Pallor removes the colour from the face, the bodies' extremities are cold,
strength languishes, the spirit is disturbed, the body restless, sleeplessness is continuous, there is lethargy
and frequent chest pains, loss of appetite, constant nausea, belching, vomiting (the vomit having the
colour of leeks or verdigris); unless this illness brings relief, very frequent sobbings wear out the poor sick
man, unquenchable thirst, trouble in passing of urine, which often make it seem that there is a [bladder]
stone, burning pain in the epigastrium [hypochondrium] sometimes without fever, more often with a
short fever and, what is the climax of the whole disease, very sharp pain in the stomach, intestines, loins,
flanks and groin racks the patient....; often, especially in the early stages, with frequent, but not copious
diarrhoea, more often with constriction of the bowels. Soon, as the poison spreads, or at least as the
acrid vapour aroused by the malignant matter spreads, the upper arms, breasts and whole chest feels as
though plucked, pricked and pierced by needles. Soon also the legs and arms are affected. There are also
those for whom the most cruel pains of the soles [of their feet] without affecting the movement, follow
the stomach pains, and recur in a more bitter fashion. It is surprising to relate that after so many pains,
the patient believes himself to be improving because the pains in the belly are remitting, he begins to feel
his arms and feet being loosened and he feels that the force which poured through all his limbs and body
is being broken. The movement of upper arm and hands, legs and feet perishes, feeling remains intact
however, and that feeling is like that of pricking needles all over the skin. In many cases this paralysis is
preceded by a number of epileptic convulsions, which once carried off many, but now fewer. A symptom
of their coming is a few hours of blindness, while the mind remains intact; often blindness remains the

97 Corn, op. cit., note 41 above.

* Philippe Grandjean, Widening perspectives of lead toxicity, Copenhagen, Fadl's Forlag, 1979.

9 The "new star" was a supernova whose initial brightness (magnitude - 4) equalled that of Venus. It was studied by Tycho Brahe. (I. S. Shklovsky, Supernovae, Chichester, J. Wiley, 1968.)

${ }^{100}$ Citois, op. cit., note 1 above. 


\section{J. Eisinger}

only symptom, lasting about seven days, while no sense other than the eyesight is affected; at that time the pains are either absent or light and are gradually soothed, if their cause is removed by timely remedies. Otherwise the pain is worsened and the epilepsy recurs, with greater danger to the patient. However, those who survive such great and so many ills, by the careful work of doctors, are bedbound for a long time, and the strength of all their members below the head, after having been affected by paralysis, gradually returns, and after several months when their strength has been restored to some extent to their limbs, they may be seen walking the streets like ghosts or statues, moving mechanically, pale, haggard and wasted, with hands turned inward and hanging by their own weight, and not raised to the mouth or other higher parts except by artificial means, and with feet moved, not by their own muscles, but by the leg muscles, so that their gait would appear ridiculous, were it not pitiful, and their voice is strident and rasping.

\section{ACKNOWLEDGMENTS}

The work presented here was made possible, in part, by a fellowship awarded by the John Simon Guggenheim Foundation and by the hospitality extended to me by the Physiological Laboratory and by Darwin College, Cambridge, England. I gratefully acknowledge the help given me by numerous scholars and librarians, and particularly that of Sir Moses Finlay, Paul Ries, Elisabeth Leedham-Green, Styra Eisinger, Adolf Laufs, and Jacques Beauroy. 